\title{
SAIL, STEAM AND EMERGENT DOCKERS' UNIONISM IN BRITAIN, 1850-1914*
}

In a well known study of the building industry written some years ago, Richard Price argued that the institutionalisation of trade unions and general formalisation of industrial relations that occurred during the latter half of the nineteenth century were influences that tended to restrict the capacity of work groups to regulate the conditions of their working lives. ${ }^{1}$ Whereas earlier labour historians, from the Webbs onwards, had emphasised the part played by formal organisations in the improvement of working conditions, Price stressed the capacity of informal groups to control the way work was conducted. Price's approach, and that of other writers adopting a similar perspective, has been extremely influential, not least because it accorded well with developments taking place in the modern industrial relations setting of the 1960 s and 1970 s, where interest was focussed upon autonomous work group activity. In the context of the mid-nineteenth century, however, Price certainly pushed his argument a long way. The capacity of craft workers, possessing a strong corporate tradition, to regulate autonomously conditions in their trade was one thing, but Price suggested that work group formation and activity extended to labourers, in building and other industries. Dock labourers, in particular, were held to have been capable of such regulative activity, "long before unionisation". ${ }^{2}$ If this was indeed the case, then the argument regarding the negative contribution of formal union organisation and collective bargaining must presumably be held to apply even in those sectors of employment where the new unionism of the 1880s and 1890s made its appearance. Such a view would appear to be in marked contrast with that adopted by writers such as Eric Hobsbawm, who have emphasised the contribution made by the national unions of 1889 to the development of the bargaining power of

\footnotetext{
* An earlier version of this paper was presented at the Anglo-Dutch Conference of Labour Historians in Maastricht, in April 1982.

1 Richard Price, Masters, Unions and Men (Cambridge, 1980).

2 Ibid., pp. 59 and 295 n.
} 
unskilled workers and, in the dockers' case, their reputation for militancy. ${ }^{3}$

In this paper it is proposed to take another look at the emergence of dockers' unionism in the period before 1914. Price does not develop his point about work group activity amongst nineteenth century dockers, his primary focus being upon the building industry, but his general proposition regarding the capacity of labourers for collective activity independent of formal union organisation may be tested against the experience of this occupational group. Studies of work group behaviour in the industry conducted in the 1960s and 1970s certainly indicated that dockers enjoyed, by comparison with workers in other industries, a high degree of control over the work process. Since ordinary dock operations had been little affected by technological change and attendant 'de-skilling', it has been suggested that the organisation of work conformed to "craft principles of administration" in which heavy reliance was placed by management on the expertise of the workforce ${ }^{4}$ Given minimal technological or managerial structuring of work organisation, it has been argued that dockers in effect established their own control. Such studies certainly make the case that 'unskilled' workers can, under certain circumstances, sustain systems of autonomous regulation of a kind normally associated with craftsmen. Furthermore, the fact that the docker's degree of control over his work was related to continuing low levels of mechanisation in the industry may suggest that a similar degree of influence over the job was attainable by earlier, possibly non-unionised, generations of dockers. Of course a whole range of influences underpinned the dockers' position after the Second World War; full employment, the dock labour scheme and institutionalised trade unionism were perhaps the most significant. Such factors limit the inferences that can be drawn for an earlier period, when the dockers' position in the labour market was much less favourable. Of the various factors, the impact of trade unionism is perhaps the hardest to evaluate. It is of course beyond the scope of this paper to discuss the problems that have confronted dockers' unionism in the post-war years, but it is important to note that the protections that are afforded to individual workers in situations where unions are recognised may contribute to the growth of vigorous, unofficial, work group activity. While there may be some truth in the view, advanced by Price and others, that work group activity constituted an "essential prerequisite" for the emergence of permanent unions, it is also likely that established trade

${ }^{3}$ E.J. Hobsbawm, "National Unions on the Waterside", in Labouring Men (London, 1964).

${ }^{4}$ See for example, Stephen Hill, The Dockers, Class and Tradition in London (London, 1976), pp. 43-55 and 196-99. Hill was of course referring to conventional operations, as opposed to work on container berths. 
unionism itself stimulated such activity. ${ }^{5}$ The relationship between formal and informal modes of organisation and activity is complex; this is a point to which we shall return.

The basic premise underlying this paper, however, concerns the significance that is to be attached to the early unions existing in the industry. Hobsbawm has argued that from the beginning the basic direction of unionism in the docks was regional and national rather than sectional and local. ${ }^{6}$ This approach entailed the view that local organisations existing before 1889 made no serious contribution to union development. The continuous history of waterside organisation was seen as stemming from the foundation of the two national unions of 1889 . Yet the history of organisation before that date is important, for two reasons. Firstly, because the adoption of a longer perspective makes it easier to identify the influences working against union growth in the industry. Secondly, because the distribution of the early unions across the range of occupational groups on the waterfront suggests a close connection between work group activity and unionisation. In other words, workers who were in a position to exercise some control over working conditions tended to resort to union organisation as a means of maintaining and extending such control. While the arrival of national unions may have complicated the position in certain respects, it does not appear that early unions operated in a restrictive fashion in relation to the aspirations of their members.

\section{I}

It must be stated at the outset, and this may be held to support Price's argument, that the dockers' capacity to engage in strike activity existed independently of formal union organisation. In Liverpool there were dock strikes in 1853, 1866 and 1879 - the last dispute was of some magnitude and shut down the port for about three weeks. ${ }^{7}$ In Hull a number of stoppages occurred in the 1870 s and there was a major strike in $1881 .{ }^{8}$ On the London waterfront there were strikes in 1853 and 1880 . In all of these movements the part played by unions was limited. And yet at the same time a persistent trend towards union formation is apparent in the industry from the mid century. In Glasgow a Harbour Labourers Union was formed in $1853 .{ }^{9}$ In

${ }^{5}$ Price, Masters, Unions and Men, p. 59. See also Richard Hyman, The Workers' Union (Oxford, 1971), p. 192 and H.A. Turner, Trade Union Growth, Structure and Policy (London, 1962), p. 86.

"Hobsbawm, "National Unions on the Waterside", p. 206.

7 E.L. Taplin, Liverpool Dockers and Seamen (Hull, 1974), chapter 3.

8 Raymond Brown, Waterfront Organisation in Hull 1870-1900 (Hull, 1972), chapter 2.

9 Webb Trade Union Collection, at the British Library of Political and Economic Science, Section A, volume XLII, 169. 
Liverpool the South End Dock Labourers Association seems to have dated from $1849 .{ }^{10}$ In London a society of watermen and lightermen was established in 1866 , although it collapsed four years later. The prosperity of the early 1870 s witnessed a major surge in activity, on the waterfront as elsewhere. The Labour Protection League, a general labour organisation that drew most of its membership from the London waterfront, was formed in 1872. Another general labour union formed in the following year, the Bristol, West of England and South Wales Operatives, also enrolled a significant number of waterside workers. ${ }^{11}$ In addition to these general organisations a crop of sectional associations also emerged, particularly in 1872 . In London the lightermen re-established their union and the coal heavers set up a society. In Liverpool the dockers at the north end of the port formed a union. ${ }^{12}$ On the Humber the lightermen established a society. Some of these small organisations perished fairly quickly, but where this occurred they were usually re-established. The Hull lightermen's society collapsed in 1881 but was revived in $1890 .{ }^{13}$ The Liverpool north end union also disintegrated, but re-emerged in 1879 along with a union of Birkenhead dockers. This organisation in turn appears to have disintegrated in the mid 1880s. The London coal heavers society quickly fell apart but was revived no less than three times within fifteen years. ${ }^{14}$ Liverpool coal heavers were more successful; their organisation enjoyed a continuous existence from $1879 .{ }^{15}$ Among Hull dockers the process of union creation, dissolution and reformation runs through from the early 1870 s to $1889 .{ }^{16}$

A few of the unions established before 1889 were, for a time, quite sizeable affairs. The Labour Protection League may have had as many as 30,000 members at its peak, organised in virtually autonomous branches, each based on a particular sectional grouping. This structure was to be revived in 1889 , by the South Side Labour Protection League. ${ }^{17}$ Most of the early waterside societies, however, were distinctly small in size. Yet they were not mere benefit clubs. In Liverpool the dockers' union formed at the

${ }^{10}$ Taplin, Liverpool Dockers and Seamen, p. 17.

${ }^{11}$ B.J. Atkinson, "The Bristol Labour Movement, 1868 to 1906", unpublished D.Phil. thesis, Oxford University 1969, pp. 172-83, 215-16 and 284-87. For a general survey of activity in the early 1870 s see S.M. Norton, "The Growth and Development of Trade Unionism among Previously Unorganised Workers in the Early 1870s", unpublished M.Phil. thesis, University of Kent 1976.

${ }_{12}$ Taplin, Liverpool Dockers and Seamen, p. 24.

${ }_{13}$ Webb Trade Union Collection, Section A, volume XLI, 34.

${ }^{14}$ Ibid., Section A, volume XLII, 266.

${ }^{15}$ R. Bean, "The Liverpool Dock Strike of 1890", International Review of Social History, XVIII (1973), p. 56.

${ }^{16}$ Brown, Waterfront Organisation in Hull.

${ }_{17}$ John Lovell, Stevedores and Dockers (London, 1969), pp. 113-14. 
north end in 1872 drew up trade rules and struck for recognition. The agitation failed, but the re-formed organisation of 1879 played an active role in the successful wages movement of $1880 .{ }^{18}$ Smallness, in any case, was not necessarily an indication of weakness. The Liverpool coal heavers' society was small because it confined itself to a small occupational group; within its job territory, however, it became a powerful force. ${ }^{19}$ In Glasgow the Harbour Labourers Union was able to impose a $£ 5$ entrance fee in 1868 , and this was subsequently raised to $£ 8 .{ }^{20}$ Of course, to the extent that the more successful of the early unions existed primarily to defend narrow job territories against infiltration by outsiders, then it is possible to suggest that they hindered rather than facilitated overall union growth in the industry. H.A. Turner, in his classic study of the cotton industry, made much of the negative impact of closed unions on the emergence of a broadly based movement, and in the context of the waterfront the allegedly archaic nature of some of the early unions has provided an additional twist to the argument. ${ }^{21}$ Thus Gareth Stedman Jones, in his study of casual labour in London, characterised the early waterside unions as belonging to a preindustrial world. "They were", he suggested, "much closer in spirit to the ancient fellowships of porters, whose privileges derived from the City of London, than to the modern general trade union." 22 Archaic or not, the exclusive societies that emerged on the waterfront were only too obviously an expression of pre-existing sectional solidarities.

To probe further into the early development of waterfront unionism it is necessary to examine more closely the distribution of unions across the range of occupations in the industry. Although waterside workers were casually employed and regarded simply as labourers, all writers have recognised that they did not constitute an undifferentiated mass. ${ }^{23}$ Specialisms abounded, since men attached themselves to particular employers or types of work. Most of these specialisms were probably artificial in the sense that they owed more to the working of the casual labour market than to real differences in the skills required to perform various jobs. There were, however, genuine skill differences, so that some specialists enjoyed real bargaining advantages over the rest. Of the genuine specialisms it can be said that some were related to the type of cargo handled, others to a

${ }^{18}$ Taplin, Liverpool Dockers and Seamen, pp. 24-25 and 60-61. It was estimated that around 5,000 dockers were involved in the 1872 strike for union recognition.

${ }^{19}$ Bean, "The Liverpool Dock Strike", pp. 56-57.

${ }^{20}$ Webb Trade Union Collection, Section A, volume XLII, 169.

${ }^{21}$ Turner, Trade Union Growth, Structure and Policy, pp. 139-68.

${ }^{22}$ Gareth Stedman Jones, Outcast London (Oxford, 1971), chapter 19.

${ }^{23}$ See for example, Gordon Phillips and Noel Whiteside, Casual Labour (Oxford, 1985), chapter 1 and David F. Wilson, Dockers (London, 1972), chapter 2. 
function performed. In the former category came the handlers of bulk commodities, corn and coal in particular, while the latter group included lightermen and shipworkers. ${ }^{24}$ There is some overlap between the two, in the sense that coal and grain handlers who were regarded as skilled were those who handled these commodities on the ship rather than the shore. Unions that exhibited some capacity for survival tended to be based on these specialist groups. Thus while the mass membership of the Labour Protection League melted away in London in the mid 1870 s the corn porters and stevedores, who were shipworkers, remained strongly organised..$^{25}$ The Lightermen in London and Coal Heavers in Liverpool provide further cases of tightly organised specialist groups. Information about the occupational composition of other surviving unions is not always available. The Glasgow Harbour Labourers appears to have been composed of shipworkers, but little is known regarding the Liverpool South End union.

In his review of waterside labour Eric Hobsbawm recognised the existence of groups of specialist workers, whose position was different from that of ordinary casuals. ${ }^{26} \mathrm{He}$ suggested, however, that such groups were incapable of providing a core around which early waterside unionism could develop. Their skills were too specific to particular localities, their numbers too small in relation to the whole. In mining the hewers were the core around which unions developed. The waterfront, he suggested, possessed no comparable group. This view can be questioned. It is true that the handlers of particular types of cargo, corn porters for example, tended to form close-knit groups operating in self-contained sectors of employment. It is less clear, however, why the large class of shipworkers should have been incapable of acting as a core group. The distinction between shipworkers and quay labourers was fundamental to the working of almost all ports. ${ }^{27}$ The purely casual, irregular, unskilled labourers were invariably confined to shore operations; employers put their regular workers on the ship. In some ports, Liverpool for example, shipworkers enjoyed a wage differential over quay labourers. Yet despite their apparently strategic position in the industry, shipworkers remained largely unorganised prior to 1889 , or even 1911. Early unions were formed amongst them, and this is of interest;

${ }^{24}$ Unlike most port workers handlers of bulk commodities were, however, to some extent exposed to the impact of mechanisation, as in the case of the introduction of elevators in the grain trade. See Lovell, Stevedores and Dockers, p. 28.

${ }^{25}$ Ibid., p. 75.

${ }^{26}$ Hobsbawm, "National Unions on the Waterside", pp. 205-11.

27 For London see Lovell, Stevedores and Dockers, chapter 2. For Liverpool see E.F. Rathbone, Labour at the Liverpool Docks (Liverpool, 1904), pp. 7-8; also Eric Taplin, The Dockers' Union (Leicester, 1986), pp. 12-13. For New York and Hamburg see C. Barnes, The Longshoremen (New York, 1915), p. 31 and appendix E, p. 212. 
such unions, however, remained small and comparatively isolated. Why did they fail to develop into more substantial organisations?

It could be argued that shipworkers as a group were not sufficiently skilled to provide a basis for union development. The men who packed the cargo in the holds, the stevedores, were of course genuinely skilled, but these constituted only a relatively small proportion of the total number of shipworkers. There may be something in this argument, but the fact remains that shipworkers as a whole were regarded as a superior group when compared to ordinary quay labourers. In any case, the part played by skill in union development is by no means a simple one. In mining, the hewers might be regarded as a skilled group, but in practice their ability to sustain stable unions varied greatly as between different mining districts. Skill is only one amongst a number of factors to be taken into account, and it seems unlikely that it was in fact the critical factor inhibiting the progress of unionisation on the waterfront.

In the period between the first formation of waterside unions in the third quarter of the nineteenth century, and the final stabilisation of mass unionism in the second decade of the twentieth, there was one major development that may well have affected the shipworkers' ability to organise and so retarded the process of union growth in the industry. This was the transition from sail to steam. Until around 1870 the total tonnage of sailing vessels continued to rise, but from that date it declined steadily for the rest of the century. ${ }^{28}$ By 1890 the tonnage of steamships had overtaken that of sail. The timing of this transition is suggestive. In the early 1870 s waterside unionism appeared to be making some progress, with significant developments occurring in London, Liverpool, Bristol and Hull. In Glasgow in 1872 the Harbour Labourers' Union, hitherto a highly exclusive body, opened its ranks to all regular dockers and launched a three week strike for a wage increase..$^{29}$ Despite these developments, however, it was not until just prior to World War I, or in some cases during the War itself, that unionism really established itself on the waterfront. The setback after the early 1870 s corresponds neatly with the impact of the steamship. Since the early 1870 s proved to be a false dawn for unionism in a number of industries, however, it would be unwise to make too much of this point.

A second point relating to the transition to steam is the circumstance that the early societies seemed to achieve a stability in spheres where sailing ships predominated that was denied to them where steamship lines were the rule. Since of course sailing ships dominated all trades in the first half of the

28 Royal Commission on the Port of London (1902), Cd.1151, Report p. 25.

${ }^{29}$ Webb Trade Union Collection, Section A, volume XLII, 170. 
century it was hardly surprising that the earliest attempts at waterfront unionism should be associated with sail rather than steam. The point is, however, that societies that established a foothold early on appeared to be able to survive, whereas those that emerged later did not. The Glasgow union was at the outset composed entirely of those engaged in loading and unloading sailing vessels. Work on the increasing number of steamers using the port was performed by unorganised labourers. As noted above, the society did attempt to expand beyond its original sphere in 1872 and reached a membership of 900 . Most of these members were quickly lost, however, and for the remainder of the period down to 1889 the society eked out a precarious existence, presumably in the diminishing area of sailing ship employment. ${ }^{30}$ It enjoyed a revival in dramatic circumstances after 1889. A link between sailing ship employment and unionism appears to exist in other ports. In New York in the 1870s a waterfront union existed called the Longshoremen's Union Protective Association. It resembled the London Labour Protection League, being a loosely organised body composed of a number of more or less independent locals. In 1874 there was a stoppage involving the whole port. It arose out of an attempt by steamship owners to reduce wages. At the outset there had been no attempt to cut wages on sailing vessels. The strike was lost and the union appears to have disintegrated in that sector of the port, the North River, where the steamship lines operated. However, on the East River and in Brooklyn, where sailing vessels docked, it seems to have survived in some strength. ${ }^{31}$ The experience of Liverpool in this period is also of interest, for here the one organisation that appears to have a continuous history from the mid century, the South End union, was based in that sector of the port where sailing vessels continued to be received. The attempt to form an organisation for workers on the steamship lines in 1872 , the union was actually called a Steamship Dock Labourers' society, met with little success, as we have seen. The pattern of events during the great strike of 1879 is also illustrative of the division between the sail and steam sectors. The strike was caused by the decision of the Steamship Owners' Association to reduce wages. The sailing ship owners organised in the Liverpool Shipowners' Association did not impose a wage cut, and the strike of the south end dockers was purely sympathetic in character ${ }^{32}$ The experience of Liverpool in 1879 was thus somewhat similar to that of New York in 1874.

The association of organisational stability with sail, and its opposite with steam, is of course a point that must not be pushed too far. Thus the ${ }^{30}$ Ibid.

${ }^{31}$ Barnes, Longshoremen, pp. 96-99.

32 Taplin, Liverpool Dockers and Seamen, pp. 34-35. 
successful union of Liverpool coalheavers was very definitely based in the steamship sector, its members (like those in the parallel London union) being engaged in loading steamers with coal as fuel. Nonetheless, the divisive impact of the transition to steam upon the shipworking core of the labour force was real enough, as will be demonstrated. Only very gradually did steam establish an ascendancy over sail on the long distance shipping routes, and in the early days at any rate steamship owners were under constant pressure to cut costs. It was significant that the strikes of 1874 in New York and 1879 in Liverpool arose out of wage reductions imposed by steamship rather than sailing ship owners. Steamship owners, furthermore, could not afford to continue the leisurely methods of cargo handling that prevailed with respect to sailing vessels. Time in port had to be kept to a minimum and this meant a faster pace of work and longer hours worked at a stretch. ${ }^{33}$ It was not, however, simply the pressures connected with the new technology that created a new set of conditions in the industry; these in any case eased somewhat over time. Of greater consequence was the fact that the maritime technical revolution was accompanied by major changes in the structure of employment at the waterside.

In the sailing ship sector, and also in the case of certain smaller steamship companies, the work of loading and unloading was usually undertaken by contractors known as master stevedores. Where unions achieved some success in regulating conditions of employment it was usually through relationships with firms of this type. Thus in the years prior to 1872 the Glasgow society was sustained by a stable relationship with master stevedores, who gave society men a preference in employment. After the early 1870 s the society's sphere of influence was considerably reduced, but when the National Union of Dock Labourers was formed in Glasgow in 1889 the old society still retained connections with a few stevedoring firms and refused to merge with the new union. ${ }^{34}$ In London the stevedores' organisation was clearly based on the sector of employment controlled by master stevedores. As in Glasgow, these employers accepted the society's rules, including the requirement that foremen be members of the union and accord to unionists a preference in employment. In the early 1890s the London master stevedores attempted to strengthen their hand in dealing with the society, by establishing the London Master Stevedores Association. The creation of this body, however, simply implied a transition from unilateral regulation to collective bargaining, and the society enjoyed con-

${ }^{33}$ Lovell, Stevedores and Dockers, pp. 26-29 and 38-40. In New York differences in working conditions as between the two sectors were seen as presenting a significant obstacle to the development of unionism; see Barnes, Longshoremen, p. 100.

${ }^{34}$ Webb trade Union Collection, Section A, volume XLII, 170-71. 
tinuous recognition from the association throughout the pre war period. ${ }^{35}$ In Liverpool there was also a link between unionism and the contractors' sector of employment. Contractors operated at the south end of the docks, and it was here of course that the oldest of Liverpool's waterside unions was established. As mentioned earlier, little is known of this South End union, but it is likely that it resembled the Glasgow and London societies. That it possessed some influence in this sector is indicated by evidence that in the $1880 \mathrm{~s}$ it imposed fines on members for working with non members. The union is believed to have had about 1,000 members in 1890 and to have retained an independent existence for some years after the establishment of the National Union in the port. ${ }^{36}$ Survival was apparently based upon the acceptance of its rules by certain firms at the south end. As significant as the survival of this old society, however, is the fact that the National Union itself came to rely to a large extent upon relations established with master stevedores and smaller shipping companies in this sector of the port. By 1903 the union had signed an agreement with the Master Stevedores' and Porters' Association, whereby the latter body agreed to accept the union's rules and in return obtained a procedure for the arbitration of disputes. ${ }^{37}$ An arbitration procedure also featured in the relations between the London Stevedores' Union and the Master Stevedores' Association, and in fact for some years the position of the National Union in Liverpool resembled that of the Stevedores' Union in London very closely indeed. Both depended for their stability on their relations with associations of master stevedores.

The apparent success of unions in influencing working conditions in those spheres of employment controlled by master stevedores can be explained in terms of the operation of a number of influences. In the first place, to the extent that these spheres corresponded with those in which the sailing ship predominated, then obviously the pressures apparent in the steamship sector were absent. Secondly, since stevedoring firms tended to be small, they lacked the resources to wage an intensive campaign against organised labour, even assuming they had wished to do so. Thirdly, being small, they may not have wished to wage such a campaign, since personal relations between employer and employed may well have been close. Finally, and perhaps most important, since master stevedores competed fairly vigorously with each other they did not, initially, present a united front to the union. Thus Stephen Sims, a secretary of the Stevedores' Union, explained that his organisation preferred to deal with master stevedores as compared

${ }^{35}$ See account in Lovell, Stevedores and Dockers.

${ }^{36}$ Bean, "The Liverpool Dock Strike", p. 57.

37 R. Bean, “Employers' Associations in the Port of Liverpool, 1890-1914", International Review of Social History, XXI (1976), p. 373. 
with shipping companies, "as these masters compete with each other and if one objects to pay the usual rate another would do so and take the work". ${ }^{38}$ However, precisely because of this competitive environment, small masters did come to perceive an advantage in dealing with a union, for a union if it was strong enough could take wages out of competition and generally stabilise conditions. In this last connection it is of interest that the Glasgow society maintained an unwritten rule that its members would not, "out of good feeling for Master Stevedores", contract directly with sailing ship owners. ${ }^{39}$

The coming of the steamship impinged on the employment structure of major ports in two main ways. Firstly, it was associated with the emergence of some very large shipping companies. Secondly, a number of these companies assumed a more or less direct control over loading and discharging operations on their vessels. The combination of these two developments, together with the general pressures associated with steamship work, appears to have created an environment that was distinctly unfavourable to unionism. In the steamship sector unions found themselves confronting not small, competing firms of master stevedores, but very large shipping concerns in control of their own stevedoring operations. At the north end of Liverpool, the area of the port dominated by large steamship lines, it was not only the early unions of 1872 and 1879 that failed to achieve stability; the National Union of 1889 was for twenty years equally unsuccessful. Of course, as R. Bean has pointed out, shipowners were not a homogeneous group, and within the steamship sector the fortunes of unionism varied..$^{40}$ Thus the National Union of Dock Labourers found it easier to survive in Birkenhead than at the north end of Liverpool, partly owing to the concentration on export work, which required a higher level of skill in the labour force, but partly also due to the intermediate size and lack of organisation of shipowners operating in the area. In London also the Dockers' Union of 1889 was recognised for a number of years by various steamship lines working from the Victoria dock..$^{41}$ In general, however, steamship companies limited or destroyed union influence, either by their own independent action or, where their individual resources were inadequate for the task,

${ }^{38}$ Webb Trade Union Collection, Section A, volume XLII, 213. Another secretary of the union, Tom McCarthy, observed that the men preferred working for master stevedores, as they were "weaker men to deal with in a dispute". Ibid. 214.

39 Ibid. 172.

${ }^{40}$ Bean, "Employers' Associations in the Port of Liverpool", pp. 373-74.

${ }^{41}$ Lovell, Stevedores and Dockers, p. 146. For more detail on this see Booth Collection at the British Library of Political and Economic Science, Group B, CXL 53-61, and CXLI 17, 37 and 76. The union's influence in this sector was, however, destroyed by the Shipping Federation following the 1900 strike, Daily Chronicle, 7-23 June 1900. 
through the support they received from employer associations. The two most important of these were the Shipping Federation and the Liverpool based Employers' Labour Association, both founded in 1890. It was of course the largest firms that were the most determined in their opposition to unions. Even without the backing of the associations, such firms were capable of evolving elaborate systems of unilateral control over employment. Bean has shown how in Liverpool the transatlantic liner companies organised their shipworkers into weekly and preference grades, a system of partial decasualisation designed to eliminate the possibility of union influence. ${ }^{42}$ The Cunard company operated such a system in New York, and it was one followed by the Allan and Donaldson lines in Glasgow. Some companies, such as Allan and Cunard, provided benefit societies for the men. ${ }^{43}$

The contrasting fortunes of unionism in the spheres of employment controlled respectively by master stevedores and steamship owners is clearly demonstrated by two disputes that occurred in Liverpool in $1905 .{ }^{44}$ At the commencement of that year the Nelson line, operating at the north end of the port, had stood out from the majority of companies in that sector through its use of a firm of master stevedores that recognised the National Union. Possibly owing to pressure from the dominant non-union firms at the north end, Nelson decided to dispense with the services of contractors and undertake its own stevedoring. The change was accompanied by a withdrawal of union recognition, and a subsequent strike failed to restore the position. The second dispute occurred at the south end, where work was generally performed by master stevedores under union conditions. In a somewhat exceptional position was the firm of $\mathrm{T}$. and $\mathrm{J}$. Harrison, a large shipping concern that undertook its own stevedoring and yet, being located at the south end, recognised the National Union. As Eric Taplin has suggested, this firm may well have compared its own position unfavourably with that of other large companies operating at the north end. Thus, seizing the opportunity presented by an unofficial strike, the firm withdrew recognition from the union and broke the strike with imported non-union labour. At both ends of the port, therefore, the events of 1905 confirmed the tendency for large shipping concerns to adopt a hostile stance towards the unions.

In the period prior to 1911 the liner companies' capacity to keep unions out was manifest in all the major ports. Walsh's comments on the Glasgow waterfront, published in 1908 as part of a general survey of dock labour,

\footnotetext{
42 Bean, "Employers' Associations in the Port of Liverpool", pp. 370-71.

43 Ibid.

${ }^{44}$ Taplin, The Dockers' Union, pp. 68-70.
} 
summarised the position neatly.$^{45}$ Walsh divided the dock labour force of the port into three classes. The first class was composed of experienced men who were for all practical purposes in the permanent employment of the large liner companies. These men received the highest average weekly earnings in the port but they were expected to work by night as well as by day. They were non-unionists. The second group was also composed of experienced workers, but these men followed the work of master stevedores. This group was unionised. The third class was made up of the real casuals, men only occasionally employed and without expertise. They were unorganised, and their average weekly earnings were much below those of the other two classes. This may be a simplified picture, but in its broad outlines it probably represents an accurate enough description of the position, not only in Glasgow, but in other ports as well.

The coming of steam and the associated changes in employment structure had, it has been suggested, a detrimental effect upon union growth on the waterfront. There is of course room for debate about the general significance of firm size and market structure, more or less competitive, as factors bearing upon union growth. Bain and Elsheikh have argued that small competitive firms may be easier to unionise than large oligopolistic or monopolistic ones, although they also suggest that the latter may be the easier to keep organised once the initial barrier to acceptance has been broken through. ${ }^{46}$ The experience of union development on the waterfront prior to 1914 would seem to conform to this pattern. In the long run greater concentration of employment in the industry may, as Hobsbawm has suggested, have facilitated the permanent organisation of the labour force ${ }^{47}$ In the shorter run, however, the emergence of very powerful employing concerns in the shape of the steamship companies made the task of the unions much harder.

The full extent of the problem faced by early unions can best be demonstrated by a consideration of the history of the London Stevedores' Society, the most important of the pre-1889 unions and the only one to have a significant history beyond that date. Operating initially within the framework of the Labour Protection League, this shipworkers' organisation was

${ }^{45}$ Report on Dock Labour in Relation to Poor Law Relief (1908), Cd. 4391, pp. 17-18. ${ }^{46}$ G.S. Bain and F. Elsheikh, "An Inter-Industry Analysis of Unionisation in Britain", British Journal of Industrial Relations, XVII number 2 (1979), pp. 142-43.

${ }^{47}$ Hobsbawm, "National Unions on the Waterside", p. 220. 
able to make rapid progress in the early 1870 s. It soon became apparent, however, that the union's position was easier to sustain against master stevedores than against steamship lines. ${ }^{48}$ In 1879 the P. and O. Line broke with the society and in the years that followed other steamship companies took a similar course. The problem was intensified by the opening of new dock systems to cater for the larger steamships that were appearing, for the union found it harder to control access to employment over this extended area. The society might have responded to the challenge of the steamship lines by recruiting the non-unionist shipworkers in their employ. In fact, however, the union's control over hiring procedures in the master stevedores' sector ruled this out, for members feared that the new recruits would either compete with them for work in those firms where the union preference was recognised or, if they remained with non-society firms, that they would compromise relations with master stevedores by working under inferior conditions. In 1881 an attempt was made to find a way around this dilemma by setting up a separate section of the union for employees of one of the largest liner companies, but this appears to have come to nothing. At last, in 1887 , the excluded stevedores in the non-society firms took matters into their own hands and formed their own organisation. During the upsurge of 1889-90 the large shipping lines were forced to make concessions to the new society and as a result of this the two organisations merged. The dilemma was, however, a recurrent one. In 1891 the major steamship companies again broke with the union. The results were almost the same as before. The society refused to allow members to continue to work at the companies in question nor would it recruit new, non-unionist, workers in this sphere. In fact numbers of members defied the rules and went to work in non-society firms, for shipping companies were ready enough to employ experienced stevedores provided they worked alongside non-unionists; as one shipowner remarked, "non-unionists give us more control of the men" ${ }^{49}$ Unionists who returned to these firms were, however, outlawed by the society. In protest, the three union branches situated in the sector of the port dominated by the large steamship lines threatened to secede from the organisation. There were even rumours that they intended to merge with the Victoria and Albert district of the Dockers' Union. In the event, nothing came of all this and the stevedores' organisation in this sector simply disintegrated.

In the 1911-14 period events repeated themselves. In 1911 the big firms were brought to heel, but broke away again in the aftermath of the disas-

48 The following account is drawn from Lovell, Stevedores and Dockers, chapters 3-7.

49 Royal Commission on Labour (1892), C.6708, Evidence Group B, volume 1, Q.6469. 
trous 1912 strike. Between 1912 and 1914 the P. and O., British India, New Zealand, Orient and White Star lines, and one large firm of contractors, all broke with the union. As in 1891 and the 1880 s the union prohibited members from working in non-society firms. In consequence former employees were forced to watch non-unionists, and on this occasion members of the Dockers' Union as well, taking their places at the firms in question. Not surprisingly, there was serious disaffection within the society, as there had been in 1891 . Of the two branches chiefly affected by the crisis, one (Albert Dock) decided after a ballot to abide by the society's instructions, while the other (Tilbury) broke away altogether and formed a separate union, an almost exact repetition of the events of 1887 . Throughout the entire period from the early 1870 s to 1914 the constant factor in the history of the Stevedores' Union was its influence over employment and working conditions in the master stevedores' sector, and it was the very stability of the society in this sphere that limited its capacity to react with flexibility to the recurrent challenge of the major steamship lines. It would be wrong to attribute the society's rigidity to a backward looking leadership. In 1909 union leaders held a ballot on the question of broadening the basis of the society to include all London port workers. The majority in favour was very narrow and in the end it was the members themselves, those working for the society firms, who refused to compromise in dealings with the liner companies.

It is likely that the dilemma of the Stevedores' Union in London found some echo in other ports. What is known of the Glasgow Harbour Labourers suggests that it was a union very similar to the Stevedores, and it certainly appears to have made an attempt to open its ranks in 1872. Like the London union, however, although to a more extreme degree, it became imprisoned in a shrinking sector of employment. The South End union in Liverpool may have faced a similar predicament, but it is the situation in Birkenhead that possibly provides the most interesting parallel. Prior to 1889 the history of organisation in this district is very shadowy, but after the arrival of the National Union a powerful union presence was established. For reasons already mentioned Birkenhead dockers enjoyed substantial bargaining advantages, and union rules relating to hiring, make-up of gangs and pace of operations were all enforced. When the National Union at last, in 1911, succeeded in obtaining a recognition agreement from the large liner companies at the north end of Liverpool, the terms were markedly inferior to those prevailing in Birkenhead. While it was undoubtedly true that the 1911 agreement was the most important breakthrough yet achieved by unionism in the sphere of the major steamship lines, the fact remained that managerial prerogatives with respect to the control of work operations 
were preserved intact. ${ }^{50}$ As is well known, the 1911 concordat was followed by a further agreement that attempted to introduce a measure of decasualisation covering the entire port area. While a variety of influences lay behind this scheme, it can in part be interpreted as the shipowners' response to the disruption of the port during the transport strike of August 1911; from this perspective decasualisation, as in the past, was seen as a means of disciplining the labour force, only on this occasion it was to be introduced on a wider scale and with the co-operation of the union. ${ }^{51}$ For many dockers also, decasualisation appeared primarily as a disciplinary device, entailing the possible erosion of established work practices and even the movement of workers between various sectors of the port. The fact that under the scheme access to dock work was to be restricted to registered workers, and control of the register was to be vested in the hands of the union and employers jointly rather than with the union alone, confirmed the suspicions of those who felt they had little to gain by change. It is significant that when the scheme was introduced, resistance was strongest in Birkenhead. The men there struck for a month in 1912, and their resistance was broken only by the importation of strikebreakers. The terms on which the National Union had been able to stabilise its position on Merseyside had thus brought it into open conflict with the most advanced section of its membership.

In this analysis the slow progress of waterside unionism has been explained in terms of the technical and structural changes that occurred in the industry after 1870 , and the organisational dilemmas that these changes created. Unions that had secured an early foothold found their path to expansion blocked by large steamship lines that performed their own stevedoring and were also prepared to adopt strenuous measures to maintain their freedom of action. At the same time, the very stability of organisation in the shrinking sphere of master stevedores' employment could, as in the case of the London Stevedores, inhibit a flexible response to the challenge posed by the liner companies. In the end, of course, the large companies were prepared to do business with the unions, but they still expected to retain a

${ }^{50}$ Bean, "Employers' Associations in the Port of Liverpool", pp. 373 and 377.

51 Ibid. pp. 378-79. See also Taplin, The Dockers' Union, chapters 7 and 8; R. Williams, The Liverpool Docks Problem (Liverpool, 1912) and the same author's The First Year's Working of the Liverpool Docks Scheme (Liverpool, 1914). For an excellent general discussion of early decasualisation schemes see Phillips and Whiteside, Casual Labour, chapters 2 and 3. 
larger share of control over employment and work operations than the more entrenched organised groups would have been willing to allow. The national unions were prepared to pay this price for recognition.

It remains to consider the nature of the relationship between informal work group activity and emergent formal unionism on the waterfront. As noted at the outset, Price has argued that union recognition and collective bargaining procedures entailed a diminution in the power of the work group. The argument rests on the assumption that workers, even in the absence of formal organisation, were able to regulate the conditions of their working lives to a substantial extent, through the operation of an elaborate web of 'customary' rules. ${ }^{52}$ From this it follows that collective bargaining curtailed the liberty of the work group by bringing such rules within the arena of joint regulation. It is in the nature of the case that the extent and depth of informal trade practices in nineteenth century labouring occupations is extremely hard to assess. It is reasonable to assume, however, that such practices were most developed among the strong bargainers on the waterfront, namely, those specialist groups that were the first to establish permanent labour unions. So far from curtailing the workers' capacity to regulate conditions in the trade, early unions were obviously seen as performing a vital function in securing the general observance of trade rules. Indeed, it was from their restrictive influence that the large steamship companies sought to break free. In those sectors where early unions were able to achieve a lasting stability, the transition from unilateral regulation by the society to a system of formalised bargaining with local masters' associations was achieved largely on the union's terms; the general framework of trade rules remained intact. The histories of the London stevedores and the Liverpool south end dockers exemplify this process.

It may be suggested, therefore, that formal procedures, in themselves, did not threaten traditional regulatory practices. They could in fact contribute to their amplification and more general observance. The real issue was rather the varying levels of recognition that unions were able to achieve. This variation in its turn was related to differences in bargaining strength across the range of occupational groups on the waterfront, differences that were based partly on skill and partly on the nature of the employing concern. What had been possible for select groups from the middle decades

52 In the context of the waterfront, the importance of custom as a means of job regulation has been emphasised by Bean. In Bean's account, however, it is the variation in customary practices that is stressed, and it is clear that in certain instances custom could work to the advantage of the employer rather than the work group. R. Bean, "Custom, Job Regulation and Dock Labour in Liverpool, 1911-39", International Review of Social History, XXVII (1982). 
of the nineteenth century onwards was not possible for the general mass of port workers, many of whom were quay labourers working for large shipping or dock companies. In any case, it is unlikely that autonomous regulation had much meaning for such groups. While it is true that cargo handling techniques generally remained primitive, it was also the case that employees of large concerns were frequently subject to a high degree of regimentation; as can be seen in the examples of the Cunard, Allan and Donaldson lines and the London dock companies. ${ }^{53}$ So far as such workers were concerned, it may be doubted whether the agreements negotiated by the national unions from 1911 onwards represented a serious infringement of work group autonomy. Of course for sections of the workforce where unionism was already strongly established, and who were encompassed by these arrangements, the situation was rather different, as was indicated by rank and file discontent on Merseyside in 1912. It was undoubtedly the case that the recognition that large employers were prepared to concede to the unions just prior to 1914 was conditional on their active participation in the enforcement of industrial discipline. Furthermore in Liverpool the previously non-union firms at the north end saw to it that the 1911 agreement ruled out union interference in methods of working cargo. The limited and conditional recognition accorded to the national unions seems to confirm Price's view as to the nature of formalised industrial relations systems. ${ }^{54}$ Yet for unions that aspired to more than a merely local significance, there was no alternative but to come to terms with the large steamship companies. The terms upon which such an accommodation could be reached might not, from the union standpoint, have been ideal, but some degree of joint regulation, on a permanent basis, was surely preferable to a continuance of unilateral managerial control, restrained only by intermittent outbursts of spontaneous insurgency. Additionally, it may be questioned whether national union officers became entangled in employer designed procedures to the extent that is implied in Price's account. As Gordon Phillips and Noel Whiteside have convincingly argued, the objectives of national union leaders, while they may sometimes have conflicted with the interests of various sections of their membership, were still not those of the employers. ${ }^{55}$ Their aim was power in the labour market, to be achieved by the closed shop, universally applied along the waterside.

${ }^{53}$ For the shipping companies see Bean, "Employers' Associations in the Port of Liverpool", pp. 370-71, and Report on Dock Labour, pp. 17-18. For the London dock companies see Lovell, Stevedores and Dockers, pp. 135-37.

${ }^{54}$ See Price's own comments on the Liverpool agreements of 1911-12: Masters, Unions and Men, pp. 201-02.

55 Phillips and Whiteside, Casual Labour, pp. 287-93. 
Thus far the argument concerning work groups has focussed on the extent to which, if at all, their activity was restricted by the advent of trade unions and collective bargaining. As indicated in the opening section of this paper, however, the relationship between formal and informal modes of organisation and activity operates in more than one direction. What is not really allowed for in Price's account is the possibility that institutionalised trade unionism may actually stimulate work group activity, even activity of a kind that is incompatible with the official policies of the organisation. A number of factors might contribute to this outcome. The operation of a closed shop, for example, would enhance the worker's security of employment. Less tangibly, membership in a trade union might contribute to a work group's awareness of its real bargaining strength. Evidence from a number of industries suggests the importance of a connection in this direction, and in the case of the development of waterside unionism some interesting possibilities arise.$^{56} \mathrm{It}$ is likely, to begin with, that the Labour Protection League, with its decentralised structure, did not merely reflect existing sectional groupings, but contributed to their further definition; as in the case of the Stevedores' Society, that evolved into an independent organisation out of various branches of the League. Again, it is at least arguable that it was the formation of the National Union on Merseyside that contributed to the development of the powerful sectional grouping of Birkenhead dockers. In London, certainly, the formation of the Dockers' Union led to the emergence of a highly assertive sectional group in the form of the Wapping wharf workers, though the Shipping Federation broke their power in $1891 . .^{57}$ The vigorous sectional activity of the corn gangs at the Albert dock might also be held to stem from their enrolment in the Dockers' Union. Examples such as these contributed to a general situation in London, in which leaders of the union feared that the recognition and closed shop that they had secured in the aftermath of the 1889 strike might be placed in jeopardy by widespread unofficial action. Apart from lightning strikes, employers complained of informal make-work practices and a drop in productivity since the establishment of the union on a mass basis. ${ }^{58}$ Despite the endeavours of union leaders to counteract these tendencies, London employers did indeed progressively withdraw recognition from the Dockers' Union, leaving it by 1900 with barely a foothold in the port. The pattern of events, so far as they concerned this union, was not dissimilar in 1911-12. It is of course true that the tight labour market prevailing in

${ }^{56}$ For some valuable general comments on this question see Neil W. Chamberlain and James W. Kuhn, Collective Bargaining (New York, 1965), pp. 159-60.

${ }^{57}$ Lovell, Stevedores and Dockers, pp. 116-17.

${ }^{58}$ Ibid., pp. 121-27. 
1889-90 and again in 1911-12 was a major factor influencing the level of work group activity, just as it underpinned the position of the Dockers' Union itself. Employers, however, undoubtedly made the connection between the closed shop and loss of control over manning levels and the pace of work operations, and they resolved to be rid of it.

In this perspective, formal trade unionism may be seen as an influence stimulating work group activity, and in the case of mass trade unions confronting powerful shipping and dock interests such activity in its turn made the task of the unions that much harder. National union leaders looked towards the transformation of the casual dock labour market as a whole, a comprehensive change entailing standardised conditions and greater regularity of employment for all dockers. Such a strategy, however, brought them into conflict both with the employers and with sections of their own membership. So far as employers were concerned the closed shop, an essential element in the strategy, was unacceptable for reasons that have been noted. As to union members, the strategy held greatest appeal for the weakest amongst them, so that work groups that had discovered a capacity to assert their sectional interests were less inclined to compromise their own immediate objectives in the interest of the long-run policy goals of the institution. This was a dilemma that the first unions, expressive as they were of well-defined sectional interests and confronting weaker employers, had been able to avoid. Their very success however, as we have seen, imprisoned them within narrow, and shrinking, job territories. 